\title{
Your Human Subjects Review Process: A Road Block or a Competitive Advantage?
}

\author{
Duncan Neuhauser $^{1 *}$, Mary Morrissey² and Mark Votruba ${ }^{3}$
}

${ }^{1}$ Department of Epidemiology and Biostatistics, Medical School, Case Western Reserve University, 10900 Euclid Ave, Cleveland OH 44106, USA ${ }^{2}$ Health Intelligence, Population Health, Health Services Executive, Republic of Ireland, Ireland

${ }^{3}$ Department of Economics, Weather head School of Management, Case Western Reserve University, Cleveland Ohio, USA

Today there is global competition for corporate and private research funding. The best students, residents and research faculty are sought after and have choices. Some countries and academic health centerleaders are realizing that having a well functioning human subject review process is a competitive advantage in this environment. Conversely a badly functioning Institutional Review Board (IRB) process could drive away mobile research funding and researchers. To the degree that this happens this could be described as "job destroying government regulation". Here we make three "minimally invasive" recommendations to turn a possible problem into an advantage.

Clinical medicine is an evidence based decision making process. Physicians recommend treatment choices for their patients based on the evidence of expected benefits to risks and costs. IRBs are rule and logic based organizations [1-3]. In rule based systems definitions become important. What is research? A narrow or broad definition could define the scope of the IRB's purview [4,5]. If the standards are met related to informed consent, free choice and privacy, etc. the research is approved. Unlike clinical medicine, this process is not driven by weighing these regulatory costs against the risks avoided and the magnitude of the social benefits.

The current IRB process was designed to fit large NIH funded research projects or big drug trials where the IRB costs are small compared to the size of the project. This process does not fit as well for student class room projects, health services research [6,7], exploratory pilot studies and quality improvement projects [8-11]. NIH grant proposals and big drug trials spell out the proposed study in minute detail. Exploratory research and quality improvement do not have such clear pre-defined plans. A totally different logic model is that of a "Learning Organization" [12] where everyone all the time is trying out better ways to meet the needs of the people being served and constantly sharing and adapting what is learned with colleagues.The IRB logic is antithetical to this model and would bring it to a halt.

\section{Promoting Good Behavior}

There are many ways that humanity promotes good behavior and discourages bad behavior: for example, civil law, criminal law, corporate hierarchies, government regulations, the market place, cultural norms, accreditation [13], professional licensure, oaths, exposure in the popular press, parental guidance, and religious commandments. Your preference for these methods may depend on whether you are a lawyer, politician, economist, medical educator, newspaper reporter or a member of the clergy.

Consider bank robberies. Perhaps you do not rob banks because your mother and your religion said this is bad, none of your friends rob banks so there is little peer pressure to do so, banks have surveillance cameras so you might get caught and go to jail. Besides, all things considered, you now have a better paying job. What if we took the logic of IRBs to this behavior? You would have to take an exam and fill out an application each time you entered the bank. Bank robbers are presumed innocent until proven guilty. This burden of proof is reversed for IRB approval. The investigator must prove innocence. Driving a car also requires an exam, a license and insurance. You do not have to get permission each time you drive, unless it is your parent's car. You can be arrested for drunken driving. The cultural norms against drinking and driving in Sweden is impressive. Instead of IRBs one could require researchers to buy insurance to compensate for harm to human subjects. Having patients themselves publish their own data and analyze it themselves is another radical solution [14].

There are several points to this bemused speculationOne is to invite wider thinking about the best way to achieve what we want. IRBs have a lot of local autonomy. Researchers trying to get approval for a study through 30 independent IRBs have discovered this [15-17]. There is an opportunity to be creative in designing the process locally. Some IRBs have low costs, are expeditious and have greater benefits. They are on the production frontier, to use the economist's jargon [18]. Others produce less benefit and have higher costs. We cannot find the frontier performers unless we measure the costs to researchers, program administration costs and the social benefits [19]. Researchers could be asked how much time they needed to complete IRB applications. The costs of the IRB office and review volunteers can be calculated. Mean time to complete the review process can be publicly reported [13]. Patient and public benefit could be measured by adding a question to routine public opinion surveys such as: Using a 10 point scale, how willing are you to participate in a medical study that might help you or patients like you? In Ireland, weekly public opinion surveys could track attitudes week by week.

\section{International Competition}

Ireland aspires to be a high technology, prosperous and humane society. They are not alone in this aspiration. However they realize that to attract research funding and the best young researchers means creating a supportive environment. Ireland does not have as much money to spend as do some other countries. Their government has decided that one way they can compete successfully is to have the best human subjects review process. This concept has been raised at the ministerial level of the government [20-22]. There is only one example we know of in the USA where an academic health center created a short

*Corresponding author: Duncan Neuhauser, Ph.D, The Charles Elton Blanchard MD, Professor of Health Management, Emeritus, Department of Epidemiology and Biostatistics, Medical School, Case Western Reserve University, 10900 Euclid Ave, Cleveland OH 44106, USA, Tel: 216-368-3726; E-mail: dvn@case.edu

Received November 10, 2011; Accepted April 18, 2012; Published April 24, 2012

Citation: Neuhauser D, Morrissey M, Votruba M (2012) Your Human Subjects Review Process: A Road Block or a Competitive Advantage? J Clinic Res Bioeth 3:130. doi:10.4172/2155-9627.1000130

Copyright: ( 2012 Neuhauser D, et al. This is an open-access article distributed under the terms of the Creative Commons Attribution License, which permits unrestricted use, distribution, and reproduction in any medium, provided the original author and source are credited. 
Citation: Neuhauser D, Morrissey M, Votruba M (2012) Your Human Subjects Review Process: A Road Block or a Competitive Advantage? J Clinic Res Bioeth 3:130. doi:10.4172/2155-9627.1000130

Page 2 of 2

statement saying that a student, resident or clinical researcher should come there because of their excellent IRB review process.

\section{Three Recommendations}

This has lead us to three "minimally invasive" recommendations based on the many ways available to promote good behavior.

1) First and foremost, every good student, resident and faculty candidate should ask: How good is your IRB process? How do you know? If enough such people ask and factor the answers into their decision-making process, countries and academic centers will be compelled to measure their IRB performance and publicly report the results.

2) Create a short statement about how good your IRB is and put it on your website. This will come to pass if enough desired candidates ask about it.

3) Think creatively about alternative ways of achieving the goals of human subject protection. For example, require investigators to pay for insurance against the risk of harm. For example, allow your visible saints (to use a concept of New England's puritans) to be excused from the documentation requirements. Change the burden of proof. Have a regional process where one approval suffices [23]. Measure your IRB performance and work to improve it. We beg for creativity.

We do not predict change will occur based on our wisdom. Change will occur under compulsion: When the best student and residency applicants turn you down. When your lethargic review process drives research money away and with it jobs. When others are gaining a competitive edge then change will be forced.Your competitors around the world would prefer that your IRB becomes more inefficient.

\section{References}

1. Neuhauser D (1994) More tales from institutional review boards. Health Matrix Clevel 4: 153-158.

2. Singer E, Levine FJ (2003) Protection of human subjects of research: Recent developments and future prospects for the social sciences. Public Opinion Quarterly 67: 148-164.

3. Morino J, Caplan AL, Wolpe PR (1998) Updating protections for human subjects involved in research: Project on informed consent, Human Research Ethics Group. JAMA 280: 1951-1958.

4. Emanuel EJ, Wood A, Fleishman A, Bowen A, Getz KA, et al. (2004) Oversight of human participants research: identifying problems to evaluate reform proposals Ann Intern Med 141: 282-291.

5. White RF (2007) Institutional Review Board Mission Creep: The Common Rule Social Science and the Nanny State. The Independent Review 11: 547-564.

6. Deming N, Wilson R, Aulisio M, Dawson N (2011) Health Services Research: A new Paradigm and What it Means for Research Oversight manuscript.

7. Green LA, Lowrey JC, Kowalsky CP, Wyszewianski L (2006) Impact of institutional review board practice variation on observational health services research. Health Serv Res 41: 214-230.

8. Brody JE (2008) A basic hospital to-do list saves lives. New York Times.

9. Editorial (2008) Pointy-Headed Regulation. New York Times.

10. Baily MA (2008) Harming through protection? N Engl J Med 358: 768-769.

11. Lynn J, Baily MA, Bottrell M, Jennings B, Levine RJ, et al. (2007) The ethics of using quality improvement methods in health care. Ann Intern Med 146: 666673.

12. Senge PM (1990) The Fifth Discipline: The Art and Practice of the Learning Organization. (1stedn), Random House, Doubleday, New York.

13. www.aahrpp.org

14. www.patientslikeme.com

15. Conforti L, Ross K, Hess B, Lynn L, Holmboe E (2008) Length of Time Needed for Institutional Review Board Approval or Exemption of Quality Improvement Projects Among Subset of US Training Programs. American Board of Internal Medicine.

16. Burman WJ, Reves RR, Cohn DL, Schooley RT (2001) Breaking the camel's back: multicenter clinical trials and local institutional review boards. Ann Inten Med 134: 152-157

17. Dziak K, Anderson R, Sevick MA, Weisman CS, Levine DW, et al. (2005) Variations among Institutional Review Board reviews in a multisite health services research study. Health Serv Res 40: 279-290.

18. Wagner TH, Cruz AM, Chadwick GL (2004) Economies of scale in institutional review board. Med Care 42: 817-823

19. Dobbs, Rebecca (2002) Evaluating Healthcare Ethics Committees. In: Perry F (ed) The Tracks We Leave: Ethics in Health Care Management. Health Administration Press, Chicago.

20. Republic of Ireland, Health Services Executive, National Research Ethics Committee Review Group Meeting, Minutes, Dublin Ireland, March 13, 2008.

21. Web site Beaumont Hospital Ethics (Medical Research) Committee, Ireland.

22. Operational Procedures for Research Ethics Committees: Guidance (2004) The Irish Council for Bioethics, Dublin, Ireland.

23. Wood A, Grady C, Emanuel JE (2004) Emmanuel, Ezekiel Regional ethics organizations for protection of human research participants. Nat Med 10: 1283 